\title{
The Teaching of Religious Education in Public Schools in the Nordic Countries of Europe
}

\author{
Vicente Llorent-Bedmar ${ }^{1} \&$ Verónica Cobano-Delgado ${ }^{1}$ \\ ${ }^{1}$ Department of Theory and History of Education and Social Pedagogy, University of Seville, Spain \\ Correspondence: Vicente Llorent-Bedmar, Facultad de Ciencias de la Educación. C/ Pirotecnia, s/n, Sevilla, \\ 41005, Spain. Tel: 34-955-420-559. E-mail: 1lorent@us.es
}

Received: September 15, 2014 Accepted: October 14, 2014 Online Published: November 15, 2014

doi:10.5539/res.v6n4p50

URL: http://dx.doi.org/10.5539/res.v6n4p50

\begin{abstract}
Christianity has constituted the cultural and ethical foundation of Europe. In the European Union (EU) a general regulation does not exist concerning religious education (RE) in schools, although there is a guarantee to parents that their children should be educated in agreement with their religious convictions.

Using the research methodology characteristic of Comparative Education, we analyzed the constitutions and distinct facets of religious education in Denmark, Finland, Norway and Sweden. The legal framework has been gleaned from these countries' respective constitutions, in which moreover the right to religious freedom is explicitly embodied, except in the case of Norway where it is implicit.

In the constitutions of Denmark and Finland, clear references are made to compulsory schooling free of charge (art. 76 and art. 16, respectively), whereas the Swedish constitution only alludes to the Government's responsibility in the area of education (art. 7.1) and the Norwegian constitution focuses on the education of the King (art. 47).

In the four countries under investigation we found that the question of religion and morality was treated with special attention. With respect to freedom to choose whether or not to take RE, while it was a compulsory subject within the school curriculum in Denmark, Finland and Sweden, since 2007 pupils in Norway have been allowed to refuse to take "Christianity, religion and philosophy".
\end{abstract}

Keywords: religion, school, Christianity, Denmark, Finland, Norway, Sweden

\section{Introduction}

In the Universal Declaration of Human Rights (10 December 1948) is enshrined the right of every citizen to receive an elementary, compulsory and free education as well as the right of parents to the choose the education they wish for their children. It is stated unequivocally that "parents have a prior right to choose the kind of education that shall be given to their children" (art. 26.3). In order for these recommendations to be put adequately into practice educational systems offer parents a diverse range of options which differ from one country to another.

Likewise, Resolution 2200 of the General Assembly of the United Nations states expressly that signatories shall “... have respect for the liberty of parents, and, when applicable, legal guardians to choose for their children schools, other than those established by the public authorities, which conform to such minimum educational standards as may be laid down or approved by the State and to ensure the religious and moral education of their children in conformity with their own convictions" (Assembly of 16 December1966: art. 13.3) (Note 1).

Under the terms of the International Covenant of Civil and Political Rights ratified by the General Assembly of the United Nations (16 December 1966), the States parties undertake to have respect for the liberty of parents or when applicable, their legal guardians to ensure the religious and moral education of their children in conformity with their own convictions (art. 18.4).

In Europe, we have the Convention for the Protection of Human Rights and Fundamental Freedoms signed in Rome in 1950, for which Council of Europe drew on the Universal Declaration of Human Rights. Although no reference was made initially to the right to education, it was regulated two years later by the Additional Protocol 1 drafted in Paris on 20 March 1952. Here it is stated that no person shall be denied the right to education and that the 
State, in the exercise of any functions which it assumes in relation to education and to teaching, shall respect the right of parents to ensure such education and teaching in conformity with their own religious and philosophical convictions (art. 2).

The jurisprudence of the European Court of Human Rights, which is the competent body for the interpretation and application of the Covenant and subsequent protocols (art. 32.1 of the Covenant), has ruled that each of the two sentences it contains should be read in the light of the other and that both should be read in the light of articles 8,9 and 10 of the Covenant (which recognizes the right to respect for private and family life, freedom of thought, conscience and religion, and freedom of expression) (Note 2), without any distinction being made between public and private education in the protection of these rights.

Traditionally the State had a monopoly on schooling, undertaking to provide the service and support it financially. This monocultural model which is removed from any sort of pluralism has been called into question from diverse points of view within Europe.

The Resolution on Freedom of Education in the European Community of 14 March 1984, calls on member States to ensure that parents can choose the type of education they wish to be given to their children, without allowing economic considerations to prevail in this decision (art. 1.9.).

The Charter of Fundamental Human Rights of the European Union (Note 3), defends the right of everyone to education (art. 14). Specifically, paragraph 3 stipulates that "the freedom to found educational establishments with due respect for democratic principles" shall be respected "in accordance with the national laws governing the exercise of such freedom and right. Parents'rights are formulated in a clear, broad, and also novel way in the statement that "the right of parents to ensure the education and teaching of their children in conformity with their religious, philosophical and pedagogical convictions"shall be respected. Thus it is acknowledged that parents have a right to ensure that their children receive a particular education in accordance with their religious or philosophical convictions but also to choose the type of education, based on certain pedagogical precepts.

In this way, States are responsible for the regulation of their respective educational systems and their curricular contents, which may implicitly involve transmitting knowledge of a moral, philosophical or religious nature. All this while respecting the right to freedom of thought, conscience and religion, a state of affairs which may turn out to be difficult to achieve.

The policies adopted within the EU seeking to establish a shared identity are fostering initiatives aimed at making national education systems more homogeneous. The controversial question of religious education in state schools poses quite a challenge to this process. From the earliest times, issues concerning freedom of religion have been dealt with in the European Parliament on many occasions. The most important steps, however, can be summed up in the Treaty of Maastricht, in which all the member States made a commitment to human rights, taking the constitutional traditions of each state into consideration. A further step was taken with the Treaty of Amsterdam, which for the first time made a clear specific reference to religion in its Declaration $\mathrm{n}^{\mathrm{o}} 11$, later included in article I-52.1 of the Treaty Establishing a Constitution for Europe (EUR-Lex, 2004). The Charter of Fundamental Rights of the EU defends the "right to freedom of thought, conscience and religion, as well as the freedom to manifest one's religion in worship, teaching, practice and observance" (art. 10.1).

The European Constitution states clearly that the "right to receive free compulsory education, the freedom to found educational establishments, and the right of parents to ensure the education and teaching of their children in conformity with their religious, philosophical and pedagogical convictions shall be respected" (art. II-74). In this way, educational freedom becomes associated with religious freedom (Note 4). Nonetheless, the differences that have not yet been resolved are patently obvious when the German version of the European Constitution, which does refer to the religious values of the EU, is compared with the official version, which, because of the position adopted by France, mentions only spiritual values.

The rejection of the Constitutional Treaty by some countries led to an institutional crisis in the EU, which was overcome with the ratification and implementation of the Lisbon Treaty, which modified the Treaty of the European Union and the Treaty Establishing the European Community. With regard to the religious question, a modification was made when the following text was included in the Preamble: "Drawing inspiration from the cultural, religious and humanist inheritance of Europe, from which have developed the universal values of the inviolable and inalienable rights of the human person, freedom, democracy, equality and the rule of law" (EUR-Lex, 2004).

After considering the different ways religion is treated in the constitutions of each member country, the difficulties of adopting a common policy on the matter are plain to see. 


\section{Objectives and Methodology}

Parents have the right to educate and to transmit their religious and moral convictions to their children, and not solely through religious education in their homes, parishes and centres of worship. States are under the obligation to facilitate the real exercise of this fundamental right, which serves both parents and pupils. Another question is how this right is developed in the education systems of the countries under study, that is, the Nordic countries of Europe: Denmark, Finland, Norway and Sweden.

With this aim, we applied the methodology characteristic of Comparative Education, following the stages proposed by García (1996) and Llorent-Bedmar (2002). As a result of our study, we present the following table in which the legal basis of RE established in the constitutions of each of the countries under study is shown.

Table 1. Constitutions, education and religion

\begin{tabular}{|c|c|}
\hline COUNTRY & STATE AND EDUCATION \\
\hline Denmark & $\begin{array}{l}\text { All children of school age shall be entitled } \\
\text { to free instruction in primary schools. } \\
\text { Parents or guardians may make their own } \\
\text { arrangements for their children or wards } \\
\text { to receive instruction equivalent to the } \\
\text { general primary school standard in their } \\
\text { homes (art. 76). }\end{array}$ \\
\hline Finland & $\begin{array}{l}\text { Everyone has a right to basic education } \\
\text { free of charge (art. 16), which will be } \\
\text { arranged by the State, municipalities and } \\
\text { private educational institutions centres } \\
\text { (art. 123). }\end{array}$ \\
\hline
\end{tabular}

STATE AND RELIGION

Citizens shall be at liberty to form congregations for the worship of God in a manner according with their convictions, provided that nothing contrary to good morals or public order shall be taught or done (art. 67).

Norway The supervision of the education of the King during his minority should, if both his parents are dead and neither of them has left any written directions thereon, be determined by the Storting (art. 47).

The purchase money, as well as the revenues of the landed property constituting ecclesiastical benefices, shall be applied solely to the benefit of the clergy and to the promotion of education. (art. 106).

Freedom of religion and conscience is staunchly defended. The right to profess and practice a religion, the right to express one's convictions and the right to be a member of or decline to be a member of a religious community (art. 11).

All inhabitants of the Realm shall have the right to free exercise of their religion. The Evangelical-Lutheran religion shall remain the official religion of the State. The inhabitants professing it are bound to bring up their children in the same. (art. 2).

The King shall at all times profess the Evangelical-Lutheran religion, and uphold and protect the same (art. 4).

More than half the number of the Members of the Council of State shall profess the official religion of the State. (art. 12).

The King ordains all public church services and public worship, all meetings and assemblies dealing with religious matters, and ensures that public teachers of religion follow the norms prescribed for them. (art. 16).

A Member of the Council of State who does not profess the official religion of the State shall not take part in proceedings on matters which concern the State Church. (art. 27). 
punished for any writing, whatever its contents, which he has caused to be printed or published, unless he wilfully and manifestly has either himself shown or incited others to disobedience to the laws, contempt of religion, morality (...) (art. 100).

$\begin{array}{ll}\text { Sweden } & \text { The government regulates education and } \\ & \text { teaching (art. 7.1) and may adopt } \\ \text { provisions with respect to any matters not } \\ \text { relating to taxation (cap. VIII, art. 7). }\end{array}$

Source: Danmarks Riges Grundlov, 1953; Kongeriket Norges Grunnlov, 1995; Suomen perustuslaki. Finlands grundlag, säädös, 1999; Sveriges grundlagar, 1975.

\section{RE in Schools}

\subsection{Denmark}

In Denmark, the principle of freedom of education was already embodied in the Constitution of 1849. The present Constitution of 1953 safeguards the right to the moral integrity of minors. The Lutheran Evangelical Church is recognized as the Danish National Church and enjoys the support of the State (art. 4). This support involves two aspects: one moral, whereby the State must show a certain consideration when legislating, with the aim of protecting the observance of religious holidays; and the other economic, apportioning financial donations from the national budget. However, the State subsidy at present makes up only a small proportion of the Church's income, which derives fundamentally from a tax which is paid by all members of the National Church. According to official data from 2012, 79.8\% of the Danish population were members of the National Church (Danmarks, 2012).

During the period of compulsory education (folkeskole) which spans the ages from 6 to 16 , RE is designated a compulsory subject and is called "Christian Studies". In the first and sixth years it consists of 60 hours' classroom attendance, while it is 30 hours in the rest, with the exception of the preparation-for-confirmation year, usually the seventh, in which the subject is not taught (European Commission, 2013). In secondary education (gymnasium), between the ages of 16 and 19, religious education is also a compulsory subject.

It is anticipated that pupils' parents can ask for exemption (García, 2006). An alternative is offered in a very small number of schools (only 41 of the 3,171 primary schools) (Mawhinney, 2007).

\subsection{Finland}

In Finland the Lutheran Evangelical Church and the Orthodox Church enjoy a special status among religious communities as regards fiscal rights, although the majority of the population is Lutheran (80\%) (European Commission, Directorate-General for Education and Culture, 2008).

$\mathrm{RE}$ has a place in the education system as a compulsory subject in primary education (ages 7 to 16) and secondary (16 to 18/19), and contributes to the computation of pupils' final average grades. In the upper secondary school there are three compulsory subjects: I. Introduction to Religion as a phenomenon, Aspects of Religion and the Bible; II: History of the Christian Faith; III: Christian Ethics.

Religious education is offered according to the religious orientation of the majority of the pupils, in this case Lutheran. Pupils who are not Lutheran may also receive religious education if their parents request it (European Commission, 2014). For these cases it is required that the religion in question be registered in Finland; that the families of those pupils who request it are members of the religious community concerned; and that there are at least three pupils making the request. In the case of Orthodox religious education, it simply needs at least three pupils to request to make the request. All RE courses must have a curriculum which has been approved by the National Educational Council. In Finland there are eleven different curricula for RE, all entitled "Religious Education" followed by the religion in question. For those pupils who do not profess any religion, an alternative subject, "Ethics", is offered.

The curricula and textbooks are the responsibility of the various religious communities. Both must be approved by the National Board of Education. 
The aim is that the subject should be as non-confessional as possible and be approached rather from a cultural perspective. For this reason the teacher is not required to belong to the corresponding religious community. He or she must only have a general qualification for which a university degree (masters) is required. The majority have studied theology at degree level and then specialized in teaching.

The new Religious Freedom Law of 2003 strengthens this position. The main contents revolve round two themes: a) basic notions of religion itself and b) tolerance towards other religions and ways of thinking. In 2004 new curricula were published and Parliament opted not to unify RE in a single subject.

If we take a forward-looking perspective, the future of Finland looks set to be significantly more multicultural. At present, multireligious schools are clustered around the large cities, especially the capital. Even in the knowledge that the possible demand on the part of religious communities for their own religious education curriculum would involve considerably greater expenditure, the position of Parliament is clear: pupils have the right to have their own religion and to be educated in it (Honkaheimo \& Luodeslampi, 2007).

\subsection{Norway}

Norway possesses a National Protestant Church, based on evangelical Lutheran religion, whose chief representative is the King and the Norwegian Parliament (Storting). The majority of the population (approximately 88\%) thus belong to the Lutheran Church, while there is also a Catholic and evangelical minority. All citizens have the right to practice freely their religion according to an amendment made to Article 2 of the 1964 Constitution:

"All inhabitants of the Realm shall have the right to free exercise of their religion. The Evangelical-Lutheran religion shall remain the official religion of the State. The inhabitants professing it are bound to bring up their children in the same." (Kongeriket Norges Grunnlov, 1995).

Norwegians consider religion an important and fundamental aspect of their lives. However, those who actively practice their religion within the country's religious communities are few; they prefer to express their religiosity in private.

In the sphere of education, Norway has undertaken to adapt the contents and values of RE to the demands of the multicultural societies of which we are all part. For this reason, from the academic year 1997/98, a new subject was introduced into the curriculum aimed at primary and lower secondary school pupils, entitled "Christian knowledge and religion and ethics education" (Kunnskapsdepartementet, 2014). This recent subject is designed to initiate pupils into a detailed knowledge of Christianity and teach about other Christian denominations as well as other world religions and philosophies of life, and ethics. The principal objectives are also to promote and respect and understanding of Christian and human values as well as dialogue and understanding between people of different religious ideologies and philosophies of life.

The country's main interest resides in promoting a curriculum which would promote union, by means of religious beliefs, of the various ethnic groups that reside in Norway.

This subject, which is aimed at all those pupils attending the country's public schools without any pretensions to converting them, seeks to uphold the parents' right to educate their children to according to their religious convictions and make decisions for their children in this share. It was precisely for this reason that a limited right to religious education was created (for example the right to remove a pupil during a period in which the course contents deal with particular topics).

Before the subject was promoted in the educational system, religious education was established by Parliament, which laid down that it should be assessed every three years. The assessment carried out in 2000 was in general very positive, particularly as regards the primary levels.

It did not entirely escape criticism, however, in particular the criticism that there was a lack of individual differentiation regarding the religious education of pupils from minority faiths or beliefs. It is also argued that this limited right does not work well enough in daily practice. As a consequence, two of the main groups outside of the National Church, such as the Norwegian Humanist Association (a non-believing association which offers its members humanist alternatives to the Christian rituals relating to the life cycle, through its programmed of civil confirmation for instance) and the Norwegian Islamic Council (a religious community with an increasing number of followers), lodged complaints concerning this limited right to reserve religious education classes. In both cases, the State has won in the courts, although both organizations have appealed and the process has not yet reached a conclusion.

Under current legislation a partial waiver is provided for those activities that involve adherence to a particular 
faith or philosophy of life, such as prayers, psalms or memorization of religious texts. In such cases the request for exemption does not require any justification. On the other hand, for requests for exemption in certain areas of the curriculum in which, according to the parents, a preference for the Christianity is inculcated over other religions or philosophies, justification is required from the parents.

In a case known as Folguerø versus Noruega (Jusdado \& Cañamares, 2007), four parents whose children were attending primary schools in the public system requested that their children be exempted from having to take the subject "Christianity, religion and philosophy". In the face of rejection by the public Administration the parents complained, in 2007, to the European Court, alleging that their rights to religious freedom and their right to educate their children according to their own convictions had been infringed and requesting total exemption from the subject. This request was rejected by the Norwegian educational authorities. The Court recognized the primacy of the parent's right over the State's position in matters of education, rejecting the Norwegian Government's argument that the claimants could send their children to private schools that were largely funded by the State. The Court added that the existence of this possibility cannot release the Government from its responsibility to guarantee pluralism in the public education system (Roca, 2008).

\subsection{Sweden}

The RE subject, "Religionskunskap", is at present non-confessional. It was established in the 1969 curriculum, replacing another which did have a confessional character: "Kristendomskunskap". The new subject is compulsory, is taught in the upper secondary school and evaluated in the same way as other subjects. Its contents focus on world religions and their traditions and its aim is to highlight the role of religions in promoting social cohesion and preventing segregation, as well as the influence of Christian traditions on the values of Swedish society (Skolverket, 2014).

For the past four decades Sweden has been undergoing transformation into a multiethnic, multicultural and multiconfessional society. This change has influenced the role RE plays in schools. On the one hand, there are those who consider it to be the responsibility of the Church and other religious groups; on the other, its inclusion in the education system is believed necessary in order for this new "multisociety" to offer an education in, and knowledge of, the various cultures and religions that comprise it (Tidman, 2005).

There is no common national curriculum, although a number of general objectives, topics and a minimum number of class-hours have been prescribed for basic education, on the basis of which each school and teacher devises their own curriculum. (Avram \& Dronkers, 2009).

The RE contents vary according to the stages of school education:

- From 1st to 3rd year: basic questions such as good and evil, what is right and wrong, friendship, gender roles, religions and places of worship in the locality, the role of Christianity and school...

- From 4th to 6th year: rituals, religious precepts and sacred places of the most important religions, Christianity and Swedish culture, love, death, being a good classmate to others...

- From 7th to 9th year: religions of the world and their history, Protestantism, Catholicism, Orthodoxy, Christianity in Sweden, moral and political ethics, sustainable development, human rights and democratic values ...

- In the 4th to 6th and 7th to 9th stages, the contents are drawn variably from four topics: religions and different schools of philosophy; religion and society; problems of identity and life problems; and ethics (Skolverket, 2014).

Confessional education is generally offered in the schools which receive a subsidy from the private sector, often organizations of a religious nature. There is also a possibility to receive confessional religious education in public schools (Gil, 2013). In such cases, schools also receive State subsidies.

\section{Final Considerations}

From our perspective, we choose to support the creation of a system in which families are in a position freely to exercise their right to choose the type of education they wish for their children.

It is quite clear that Christianity plays an important role in European societies, providing a framework and direction for models and ways of life for the majority of their citizens. Considered a cornerstone of these societies, as well as a vital means of transmitting values, Christianity, embedded in the cultural and ethical foundations of Europe, has been a constituent element in the development of the European states and their national education systems. RE, then, is far from being a trivial matter. For example, in all EU countries except France, this subject is integrated within the school setting. 
Regarding the countries studied we observed that the legal framework of RE has been embodied in the constitutions of Denmark, Finland, Norway and Sweden. The right to religious freedom is moreover enshrined in all of them, implicitly so in the case of Norway.

In the constitutions of Denmark and Finland clear reference is made to compulsory schooling free of charge (respectively, arts. 76 and 16), while the Swedish constitution refers only to Government responsibility in the sphere of education (art. 7.1) and the Norwegian constitution focuses on the education of the king (art. 47).

Independently of whatever legislative measures are adopted in particular circumstances and for eminently political reasons, a number of States have close ties with religion and consider the Church as somehow belonging to them.

In the four countries studied special attention is given to how the question of religious and morality is dealt with. In Denmark and Norway the Lutheran Evangelical Church is recognized as the National Church, and enjoys State support. So much is this the case that the monarchs of these two countries are obliged to belong to it as members.

There is no explicit allusion to RE in the constitutions of Denmark, Finland and Sweden, while in Norway the constitution states that citizens professing the official State religion, the Lutheran Evangelical, are obliged to educate their children in it.

As far as the freedom to opt for RE or not, we find a number of States that establish it as a compulsory subject in the school curriculum. Such is the case in Denmark, Finland and Sweden. In Norway, since 2007, pupils have been able to refuse to take the subject "Christianity, religion, and philosophy", the king being responsible for ensuring religious education teachers in public school follow the norms established for this area.

No alternatives to RE are offered in Denmark, Norway and Sweden. There are however optional subjects in Finland.

Generally speaking, the subject content and textbooks of these countries are chosen and approved by the various religious confessions, then subsequently ratified by the educational authorities; in Finland the teachers are allowed to choose the material themselves

However, if education is primarily a parental activity, other agents are delegated by and subordinate to them. Although they may have recourse to others to assist them, parents are always those principally responsible for the education of their children. School must be seen in this context: as an institution designed to assist parents in their educational endeavors.

We concur with the immense majority of international declarations and national constitutions in affirming that it is the right and duty of parents to educate their children. Since the ultimate purpose of the educational process is the holistic development of the students, all their faculties and potential must be deployed to give them the kind of education that will help them become independent people with their own ideals. Clearly, for those with religious principles, the religious dimension should also be included in the education of their children. Another question would be how to carry this out while at the same time reconciling it with the rights of the other pupils, even if in the case of citizens of the EU they are in the minority.

\section{References}

Avram, S., \& Dronkers, J. (2009). Religiosity and Education in Europe. European University Institute. Retrieved from Religiosity_Education.pdf http://www.esri.ie/research/research_areas/education/Remc/working_papers/REMC_

Anderson, C. A., Gentile, D. A., \& Buckley, K. E. (2007). Violent video game effects on children and adolescents: Theory, research and public policy. United Kingdom, Oxford University Press. http://dx.doi.org/10.1093/acprof:oso/9780195309836.001.0001

Danmarks, R. G. (1953). Retrieved from http://www.grundloven.dk/

Danmarks, S. (2012). Members of the national church. Danmarks Statestik. Retrieved from http://www.dst.dk/en/Statistik/emner/folkekirken/medlemmer-af-folkekirken.aspx

EUR-Lex. (2004). Tratado por el que se establece una Constitución para Europa. Diario Oficial de la Unión Europea, 47, 1-480.

European Commission. (2013). Denmark. Eurypedia-The European Encyclopedia on National Education System. Retrieved from https://webgate.ec.europa.eu/fpfis/mwikis/eurydice/index.php/Denmark:Overview

European Commission. (2014). Finland. Eurypedia-The European Encyclopedia on National Education System. 
Retrieved from https://webgate.ec.europa.eu/fpfis/mwikis/eurydice/index.php/Finland:Overview

European Commission. Directorate-General for Education and Culture. (2008). The information database on education systems in Europe. The education system in Finland (2007/2008). Bruselas, European Commision.

García, J. L. (1996). Fundamentos de educación comparada. Madrid, Dykinson.

García, J. L. (2006). La enseñanza religiosa escolar en la Unión Europea. Revista Bordón, 58, 615-626.

Gil, A. (2013). La religión no es evaluable en la mitad de la Unión Europea. Diario.es. Retrieved from http://www.eldiario.es/sociedad/asignatura-religion-Europa_0_136836467.html

Honkaheimo, M. Y., \& Luodeslampi, J. (2007). Religious Education in Finland. The European Forum for Teachers of Religious Education. Retrieved from http://www.mmiweb.org.uk/eftre/reeurope /finland_2009.html

Jusdado, M. A., \& Cañamares, S. (2007). La objeción de conciencia en el ámbito educativo. Comentario a la Sentencia del Tribunal europeo de Derechos humanos Folguerø v. Noruega. Revista General de Derecho Canónico y Derecho Eclesiástico del Estado, 15, 1-14.

Kongeriket Norges Grunnlov. (1995). De 17 de Mayo de 1814. Asamblea Constituyente. Enmendada el 23 de julio de 1995.

Kunnskapsdepartementet. (2014). National Report from Norway. Retrieved from http://www.regjeringen.no/nb/dep/kd/dok/rapporter_planer/rapporter/2001/the-development-of-education-1 991-to-200/2.html?id=277459

Llorent-Bedmar, V. (2002). Educación comparada. Sevilla, Universidad de Sevilla..

Mawhinney, A. (2007). Freedom of religion in the Irish primary school system. Legal Studies, 3, 179-403.

Roca, M. J. (2008). Deberes de los poderes públicos para garantizar el respeto al pluralismo cultural, ideológico y religioso en el ámbito escolar. Revista General de Derecho Canónico y Derecho Eclesiástico del Estado, 17, 1-37.

Skolverket. (2014). Kursplan-Religionskunskap. Retrieved from http://www.skolverket.se /laroplaner-amnen-och-kurser

Suomen perustuslaki. (1999). Finlands grundlag, säädös 11. Kesäkuuta.

Tidman, N. (2005). Religious Education in Sweden. The European Forum for Teachers of Religious Education. Retrieved from http://www.mmiweb.org.uk/eftre/reeurope/sweden_2005.html

\section{Notes}

Note 1. We can find statements in the same vein in the European Convention on Human Rights (2-III-1952), and in the European Social Charter of Social Rights (1961).

Note 2. Sentences Kjeldsen, Busk Madsen and Pedersen versus Denmark of 7 December 1976 (TEDH 1976\5, series A no. 23), § 52; Valsamis versus Greece, of 18 December 1996 (TEDH 1996\70, Collections of sentences and resolutions 1996-VI) § 25; Folgerø and others versus Norway, of 29 June 2007 (TEDH 2007\53) § 84 a); and Hasan and Eylem Zengin c. Turkey, of 9 October 2007 (TEDH 2007\63), § 47.

Note 3. Adopted 7 December 2000 (DOCE num. 364, 18 December), revised by an Agreement of 12 December 2007 and incorporated into European Community Law by the Lisbon Treaty signed on 13 December 2007, which entered into force on 1 January 2009.

Note 4. Conference of Government representatives of member States. Treaty Establishing a Constitution for Europe. Brussels, 13-10-2004. (OR. fr). CIG 87/1.

\section{Copyrights}

Copyright for this article is retained by the author(s), with first publication rights granted to the journal.

This is an open-access article distributed under the terms and conditions of the Creative Commons Attribution license (http://creativecommons.org/licenses/by/3.0/). 